\title{
LETTER
}

\section{Th17 mediators and vitamin D status in influenza A (H1N1)}

\author{
Goran Krstić* \\ See related research by Bermejo-Martin et al., http://ccforum.com/content/13/6/R201 and related letter by Krstić, \\ http://ccforum.com/content/14/2/410
}

Regarding Bermejo-Martin and colleagues' article [1] and my comments [2], the authors concluded in their response that 'vitamin D should thus be considered in the context of a wider spectrum of factors influencing severe disease'. Although this is a reasonable proposal, it should be emphasized that vitamin $\mathrm{D}$ has been recognized as an important immuno-modulating factor [3], and studies show that both obesity [4] and seasonal sunlight deprivation [5] play important roles in the severity of influenza, not just in the western countries, where obesity is widely present, but worldwide. Overall better living conditions coupled with a disproportionately better health-care system could explain the absence of a significantly higher incidence of obesity-related critically ill $\mathrm{H} 1 \mathrm{~N} 1$ patients in the western versus the developing countries.

Regarding the exposure to sunlight, which is well correlated with vitamin D synthesis in the skin, there is a variation throughout the world largely due to differences in the geographical latitude. Populations have adapted to the regional intensity of the solar irradiation in different latitudes through evolutionary changes in skin pigmentation [6]. Hence, when compared to the natives of higher latitudes, people in the tropical regions may require longer periods of a direct skin exposure to intense sunlight to generate physiologically required quantities of vitamin D. The problem of insufficient-solar-irradiationrelated vitamin D deficiency becomes prominent particularly in darker-skinned migrant populations when they move to higher latitudes $[7,8]$. This could be translated into a higher risk of developing severe illness if exposed and infected by an influenza virus, which should be taken into consideration when treating critically ill patients.

\section{Competing interests}

The author declares that he has no competing interests.

Published: 17 May 2010

\section{References}

1. Bermejo-Martin JF, Ortiz de Lejarazu R, Pumarola T, Rello J, Almansa R, Ramírez P, Martin-Loeches I, Varillas D, Gallegos MC, Serón C, Micheloud D, Gomez JM, Tenorio-Abreu A, Ramos MJ, Molina ML, Huidobro S, Sanchez E, Gordón M, Fernández V, Del Castillo A, Marcos MA, Villanueva B, López CJ, RodríguezDomínguez M, Galan JC, Cantón R, Lietor A, Rojo S, Eiros JM, Hinojosa C, et al.: Th1 and Th17 hypercytokinemia as early host response signature in severe pandemic influenza. Crit Care 2009, 13:R201.

2. Krstić G: Th17 mediators and vitamin D status. Crit Care 2010, 14:410.

3. Cutolo M: Vitamin D and autoimmune rheumatic diseases. Rheumatology 2009, 48:210-212.

4. Louie JK, Acosta M, Winter K, Jean C, Gavali S, Schechter R, Vugia D, Harriman K, Matyas B, Glaser CA, Samuel MC, Rosenberg J, Talarico J, Hatch D; California Pandemic (H1N1) Working Group: Factors associated with death or hospitalization due to pandemic 2009 influenza $A(\mathrm{H} 1 \mathrm{~N} 1)$ infection in California. JAMA 2009, 302:1896-1902.

5. Cannell JJ, Zasloff M, Garland CF, Scragg R and Giovannucci E: On the epidemiology of influenza. Virol J 2008, 5:29.

6. Jablonski NG, Chaplin G: The evolution of human skin coloration. J Hum Evol 2000, 39:57-106.

7. Hintzpeter B, Scheidt-Nave C, Müller MJ, Schenk L, and Mensink GBM: Higher prevalence of vitamin $D$ deficiency is associated with immigrant background among children and adolescents in Germany. J Nutr 2008, 138:1482-1490.

8. Genuis SJ, Schwalfenberg GK, Hiltz MN, Vaselenak SA: Vitamin D status of clinical practice populations at higher latitudes: Analysis and applications. Int J Environ Res Public Health 2009, 6:151-173.

doi:10.1186/cc8995

Cite this article as: Krstić G: Th17 mediators and vitamin D status in influenza A (H1N1). Critical Care 2010, 14:417.

*Correspondence: Goran.Krstic@fraserhealth.ca

Fraser Health, Environmental Health Services, 537 Carnarvon Street, New Westminster, BC, Canada V3L 1C2 